\title{
The importance of the professional Psychologist in hospital emergencies in Brazil
}

\author{
Alexsandra Alves Bezerra de Lima ${ }^{1}$; Elaine Cristina da Silva Gomes Ferreira ${ }^{2 *}$; Evelly Beatriz \\ Honório de Lima ${ }^{3}$ Maria Jose da Silva Mendes ${ }^{4}$; Natalia da Silva Santos ${ }^{5}$; Veridiana Maria da Silva ${ }^{6}$; \\ Pierre Teodosio Felix ${ }^{7}$
}

1 - 6 Psychology Students at University Center of Vitória de Santo Antão (UNIVISA), Vitória de Santo Antão, Pernambuco, Brazil

7 Professor of Psychology course at University Center of Vitória de Santo Antão (UNIVISA), Vitória de Santo Antão, Pernambuco, Brazil

E-mail adresses: sandraablim@hotmail.com (Alexsandra Alves Bezerra de Lima), elainecsgomes2014@gmail.com (Elaine Cristina da Silva Gomes Ferreira), evelly.202114062@univisa.edu.br (Evelly Beatriz Honório de Lima), m.silvamendes86@gmail.com (Maria Jose da Silva Mendes) natalia.202114006@univisa.edu.br (Natalia da Silva Santos), veridiana.202114153@univisa.edu.br (Veridiana Maria da Silva), pierrefelix@univisa.edu.br (Pierre Teodosio Felix)

${ }^{*}$ Corresponding author

\section{To cite this article:}

Lima, A.A.B.; Ferreira, E.C.S.G.; Lima, E.B.H.; Mendes, M.J.S.; Santos, N.S.; Silva, V.M.; Felix, P.T. The importance of the professional Psychologist in hospital emergencies in Brazil. International Journal of Sciences. Vol. 2, No. 3, 2021, pp.83-85. ISSN $2763-5392$.

Received: 10 17,2021; Accepted: 10 18, 2021; Published: 11 03, 2021

\begin{abstract}
In the hospital emergency department, daily routines of situations resulting from accidents of various orders are lived; unexpected and consequences for patients and family members. Among these, sadness, fear and uncertainties stand out. These consequences, which are also experienced by the team of professionals who work in the emergency room, are factors that alter emotions; drawing special attention to the work of the professional psychologist in hospital emergency. In this study, a series of compilations of several databases composed of national and international authors were used to show the importance of the Psychologist in hospital emergency.
\end{abstract}

Keywords: Emergency. Hospital Psychology. Psychologist.

\section{Introduction}

Emergency psychology studies people's behavior in accidents and disasters from preventive to post-trauma and, if applicable, subsidizes interventions to understand, support and overcome trauma to victims and first responders. The subject extends to issues ranging from the personal experience of posttraumatic stress to adverse events caused by calamities, whether natural and/or man-made (SILVA et al., 2019).

The psychologist undermeasures the team/patient relationship: this professional is the spokesperson for needs, desires, and intervenes in such a way that information mismatches are minimized. Preferably, it should always collaborate with the same team, in order to promote the development of a common language and reciprocal knowledge, necessary for joint interaction aiming at the unison approach of the patient and his family. Having a clinical, social, organizational role, with areas of activity that cover Preventive and Treatment Psychology, before the professional's performance within a Hospital institution. In the emergency and emergency environment, the relationship of the psychologist with the other professionals of the health team should cover all the possibilities of this interaction, and always attentive to the other interventions that may occur during the development of their activities, without forgetting that it is a catalyst of the emotional processes arising within the institutional reality. The psychologist collaborates with the team working on patient preparation by helping him to control his anxiety by providing adequate and sufficient information; assisting in the creation of a climate of trust between doctor and patient; allowing the patient to verbalize the fears raised by the prospects of treatment; one can talk about pain, discomfort, rehabilitation and life restructuring (VIEIRA, 2010).

\section{Methodology}


This is a study with data collection based on bibliographic data collection. For this survey, articles were retrieved in several databases such as the Virtual Health Library (VHL), Scientific Journal of the RCFMC School of Medicine, PubMed and Scientific Electronic Library Online (SciELO). The inclusion criteria determined for the selection of articles were: texts available in full, articles in Portuguese; master's dissertations and doctoral theses and articles in the integra that portray psychology in hospital emergency.

\section{Results and Discussion}

The patient when entering the emergency room finds himself immersed in a situation of helpless and, in a way, loses his dignity when he leaves his position as a subject to the object of intervention. It is submitted to medical procedures that, although they aim at its improvement, can acquire a threatening and invasive character. Thus, he lives a moment of loss of reference, which is accompanied by experiences of isolation, abandonment and disruption of affective, professional and social ties. But this suffering that permeates the passage of the patient through the emergency room (ER) can be minimized by psychological intervention the emergency room is the place where one arrives not only with physical pain, but also, with psychic pain; where both allow the triggering of unique experiences and, in this sense, point out the need for the psychologist's action in medical emergencies, welcoming and humanizing, sharing with the actors, patient, family and team, their anguish. This professional is responsible for the rapid and adequate insertion of emergency psychological interventions in this new work environment that is defined. Recognizing the psychic impact on the patient, team and family triad in the Medical Emergency point to the need for the psychologist's insertion in this team, minimizing all suffering coming from the unexpected of illness and this is a first step towards innovation in Reception and Humanization within the Emergency and Emergency Medical Unit. (VIEIRA, 2010)

We need to mobilize the spirit to control our eyes, we need to mobilize our eyes to control our spirit." The understanding of this in finishing is what makes it possible to sensitize one's change. Change in the question, change in the look that, in turn, can operate the transformation of what is often seen as an isolated phenomenon. Such as a disaster, an accident or a catastrophe. In this theme of emergencies, there are many variables that determine how someone will be affected by traumatic stress, including age, experience, expectations, interpretations, understanding and perceptions of the traumatic event. The recovery of a traumatic event can be influenced by the personality, nature of the stressors experienced, coping resources, support resources and the nature of adaptation, which may involve a positive change of character. (ABUEG, 2004).

The organization and functioning of psychology services in a general hospital can be in two ways: Consulting System and Liaison System. In the first, the psychologist evaluates, indicates and/or performs a treatment for the patient who is under the care of other professionals. The presence of the psychologist is episodic, responding to a specific request from another professional. Its work is based on assisting in the diagnosis, treatment, action plan, providing guidance to patients, family members and team members (BRUSCATO, 2004).

Thus, the psychologist in the hospital context would have the clinical role, but also the social, organizational and educational role in the form of psychological care, which would include, as clients, in addition to the patient and his/her family members, the multidisciplinary team and other hospital employees, covering activities of counseling, consulting and psychological inter-consultation. (CAMPOS, 1995).

The risk of the increasing incidence of Burnout Syndrome in professionals who deal directly with patient care suggests that projects aimed at caring for these professionals with activities in groups and individuals, may reduce moments of crisis, anguish and confusion and this type of care can become a reference, enabling contact with internal and external resources (KOVACS, 2010).

Psychological care to the health team is a demand that has been studied due to the emotional burden involved in this work.

\section{Conclusions}

Hospital psychology has the role of mediating the relationships between users and the health team, identifying the main demands that generate impact on mental health, assisting directly or indirectly, in adapting to the process of illness, and strengthening the coping resources of those involved. We work with technical questions of psychology, but also with guiding processes, psychoeducation, team training, complementary preparation of response teams, and with the individual or group emotional demands that arise in the process (BARBOSA, 2007).

In this sense, the psychologist, while a mental health professional seems to be the main agent of transformation in these cases, since his work involves welcoming, listening, care, guidance and referral to the health units of the mental health network (GONDIM, 2015).

The need for the psychologist working in the emergency department points to improvements in the care provided to the patient, the family, enabling the health team to provide a more adequate service.

\section{Acknowledgements}

To Professor Dr. Pierre Teodosio Felix for trust, correction and encouragement. For providing knowledge, motivation and growth.

\section{References}

[1] ABUEG, F. R. et al. Trauma de desastre. In: DATTILIO, F. M. Estratégias cognitivo: comportamentais de 
intervenção em situações de crise. Porto Alegre: Artmed, 2004.

[2] BARbosA, L. N. F., Francisco, A. L., Efken, K. H. (2007) Adoecimento: o ser-para-a-morte e o sentido da vida. Pesquisas e Práticas Psicossociais. 2: 54 - 60.

[3] BRUSCATO, W. L. (2004). A Psicologia no Hospital da Misericórdia: um modelo de atuação. In W. L. Bruscato, C. Benedetti, \& S. R. A. Lopes. A prática da psicologia hospitalar na Santa Casa de Misericórdia de São Paulo: novas páginas em uma antiga história, (pp. 17-32). São Paulo: Casa do Psicólogo

[4] CAMPOS, T. C.P. Psicologia Hospitalar: a Atuação do Psicólogo em Hospitais. São Paulo: EPU,1995.

[5] GONDIM, D. S. M. (2015). A intervenção da psicologia: tentativas de suicídio e urgência hospitalar. Revista Científica da FMC. v. 10 n. 2 (2015).

[6] KOVÁCS, M. J. (2010). Sofrimento da equipe de saúde no contexto hospitalar: cuidando do cuidador profissional. O mundo da saúde, 34(4), 420-429.

[7] SILVA, Pollyane Lisita da; NOVAIS, Marina Rodrigues e ROSA, Isabela de Oliveira.A função do psicólogo no pronto-socorro: a visão da equipe. Rev. SBPH [online]. 2019, vol.22, n.2, pp. 149-169. ISSN 1516-0858.

[8] VIEIRA, M.C. (2010). Atuação da Psicologia hospitalar na Medicina de Urgência e Emergência. Rev Bras Clin Med. São Paulo, 2010 nov-dez;8(6):513-9. 